\title{
Exposure as Collected Category
}

National Cancer Institute

\section{Source}

National Cancer Institute. Exposure as Collected Category. NCI Thesaurus. Code C117475.

A classification of collected exposure data. 